УДК 636.4.084/087

(C) 2017

Заїка О. А., аспірант

(науковий керівник - доктор сільськогосподарських наук, професор А. А. Поліщук)

Полтавська державна аграрна академія

\title{
ВПЛИВ МЕЛАНІНУ НА ПРОДУКТИВНІСТЬ МОЛОДНЯКУ СВИНЕЙ ПРИ ВІДЛУЧЕННІ
}

\section{Рецензент - кандидат біологічних наук Н. В. Чижанська}

\begin{abstract}
Представлені дані по вивченню ефективності застосування меланіну, продуцентом якого $є$ дріжджеподібні гриби Nadsoniella nigra штам X-1, в раціонах поросят при відлученні. Встановлено позитивний вплив даної добавки на підвищення середньодобових приростів молодняку свиней.

В дослідних групах тварин, яким до кормів додавали меланін, продуцеентом якого є дріжджеподібні гриби Nadsoniella nigra штам X-1, середньодобові прирости поросят у період відлучення, а саме в 45 днів були вищими на 13,7\% порівняно з показником контрольної групи. Зважування молодняку свиней в 50 днів, у період адаптації після відлучення, показало, що середньодобові прирости в дослідній групі тварин підвищувалися і становили 445 г, що на $25 \%$ вище порівняно з показниками контрольної групи. Це пов'язано з тим, що меланін сильний адаптоген.
\end{abstract}

Ключові слова: біологічно активні добавки, ефективність, рачіон, меланін, молодняк свиней, середньодобовий приріст, продуктивність.

Постановка проблеми. 3 метою підтримання високої резистентності тварин на стійкість до різних захворювань в склад преміксів додають біологічно - активні речовини, антиоксиданти та інші речовини, що мають велике значення [1-3, $5,7,8]$. Водночас останнім часом відмічається використання препаратів, які відрізняються широким спектром дії $[2,5,7,8]$. Тому поява кожного нового препарату вітчизняного виробництва стимулюючої дії, біологічного захисту проти різних захворювань і т. д. являє собою великий інтерес і має велике господарське значення.

Аналіз останніх досліджень і публікацій, у яких започатковано розв'язання проблеми. На сьогодні генетичний потенціал продуктивності свиней повною мірою не реалізується, конверсія кормів залишається низькою, має місце великий відхід поросят у перші два місяці життя та відставання їх росту в наступні вікові періоди, рентабельність галузі низька. Все це пов'язано не тільки з селекцією, але й недосконалістю годівлі тварин [7]. Для вирішення питання про розвиток повноцінного постнатального періоду в поросят вченими активно ведуться дослідження біологічно активних добавок, які в майбутньому можна застосовувати в основних раціонах свиней $[4,6,8]$.

Критерієм нормального росту поросят-сисунів є динаміка їх живої маси та середньодобових приростів. Сьогодні достовірно відомо, що маса поросят під час відлучення і темпи росту в перші 5-7 днів після нього значно впливають на ефективність відгодівлі свиней від відлучення аж до забою. Ось чому в цей період необхідно забезпечити інтенсивний ріст і добре здоров'я поросят. Відлучення - це критичний період їх життя, коли закладаються основи для майбутнього росту i розвитку. Зміна раціону зумовлює виникнення так званого кормового стресу $[5,6,8]$.

Досвідчені тваринники добре знають, що зміна раціону в поросят супроводжується досить тривалим (іноді до 5-7 діб) періодом адаптації тварини до споживання нового корму. Зміна раціону різко знижує поїдання корму, і адаптаційні механізми ініціюють процес розпаду запасів енергії тіла на протистояння стресу. За даними науковців $[5,8]$ шляхом включення в корми добавок, які володіють антиоксидантними властивостями та регулюють фізіологічні процеси організму $[6,10,9]$, можна досягти високих показників продуктивності та збереженості поросят під час відлучення.

Метою наших досліджень було вивчити ефективність застосування меланіну, продуцентом якого є дріжджеподібні гриби Nadsoniella nigra штам X-1, в раціонах поросят під час відлучення.

Матеріали і методика дослідження. Дослідження проведені в господарстві ТзОВ «Сторожове» Чутівського району Полтавської області. В дослід всього було залучено 140 тварин у період відлучення. Контрольна група складалась зі 100 тварин, яких у період відлучення утримували на кормах власного виробництва без включення меланіну. Дослідна група складалась із 40 поросят. 
Вплив меланіну, продуцентом якого с дріжджеподібні гриби Nadsoniella nigra штам X-1, на продуктивність поголів'я поросят під час відлучення

\begin{tabular}{|c|c|c|c|c|c|}
\hline \multirow{2}{*}{ Показник } & \multirow{2}{*}{ Група } & \multirow{n}{*}{} & \multicolumn{3}{|c|}{ Період росту, днів } \\
\cline { 4 - 6 } & & & 42 & 45 & 50 \\
\hline \multirow{2}{*}{ Жива маса } & Контроль (чисті комбікорми) & 100 & $10,67 \pm 0,220$ & $11,69 \pm 0,205$ & $13,46 \pm 0,258$ \\
\cline { 2 - 6 } & Дослід (комбікорми + меланін) & 40 & $10,61 \pm 0,158$ & $11,77 \pm 0,189$ & $14,00 \pm 0,210$ \\
\hline $\begin{array}{c}\text { Середньо- } \\
\text { добовий } \\
\text { приріст, г }\end{array}$ & Контроль (чисті комбікорми) & 100 & $0,322 \pm 0,015$ & $0,341 \pm 0,028$ & $0,354 \pm 0,035$ \\
\cline { 2 - 6 } & Дослід (комбікорми + меланін) & 40 & $0,320 \pm 0,022$ & $0,388 \pm 0,031$ & $0,445 \pm 0,028$ \\
\hline
\end{tabular}

Примітка: $\mathrm{n}$ - кількість експериментальних тварин у групі

Тваринам цієї групи до кормів власного виробництва протягом 8 днів (3 дні до та 5 днів після відлучення) додавали меланін 3 розрахунку 0,1 мг/кг один раз на добу, у вигляді водного розчину, який готували безпосередньо перед годівлею.

Групи тварин формували 3 урахуванням маси тіла, фізіологічного стану поросят та терміну опоросу свиноматок.

Результати дослідження. В контрольній групі тварин згодовували зернову кормосуміш власного виробництва, до складу якої входили дерть ячмінна - $40 \%$, пшенична - $20 \%$, кукурудзяна $20 \%$, соєвий шрот - $10 \%$ та екструдований гоpox $-10 \%$.

Показано, що в контрольній групі тварин середньодобові прирости поросят у період росту в 42, 45 та 50 днів становили в грамах: 322, 341 та 354 відповідно (див. табл.).

\section{БІБЛІОГРАФІЯ}

1. Ванжула Ю. І. Вплив згодовування бовілакту на перетравність поживних речовин раціонів у свиней / Ю. І. Ванжула // Вісник Полтавського державного сільського сподарського інституту. 2001. - №2-3. - C. 129-131.

2. Вержевська О. П. Перетравність поживних речовин у молодняку свиней різного походження при різному рівні годівлі / О. П. Вержевська // Вicник Полтавського державного сільськогосподарського інституту. - 2001. - №2-3. - С. 131-133.

3. Застосування сполук селену для профілактики оксидаційного стресу у поросят раннього віку / [Бучко О. М., Данчук В. В., Снітинський В. В., Антоняк Г. Л.] // Наук. вісник Націон. агр. ун-ту. - 1998. - №10. - С. 156-163.

4. Пінчук С. М. Вплив «Гуміліду» на лейкоцитарний профіль крові поросят раннього віку / С. М. Пінчук // Вісник Дніпропетровського державного аграрно-економічного університету. №2 (34). - 2014. - C. 205-207.

5. Полішук $A$. А. Біологічно активні речовини в раціонах поросят / А. А. Поліщук // Тваринництво України. - 1997. - №8. - С. 20.
У дослідних групах тварин, яким до кормів додавали меланін, продуцентом якого є дріжджеподібні гриби Nadsoniella nigra штам X-1, середньодобові прирости поросят в період відлучення, а саме в 45 днів були вищими на 13,7 \% порівняно $з$ показником контрольної групи. Зважування молодняку свиней в 50 днів, в період адаптації після відлучення, показало, що середньодобові прирости в дослідній групі тварин підвищувалися і становили - 445 г, що на $25 \%$ вище порівняно з показниками контрольної групи. Це пов'язано з тим, що меланін сильний адаптоген.

Висновок. Таким чином наші дані свідчать про те, що меланін, продуцентом якого є дріжджеподібні гриби Nadsoniella nigra штам X-1, сприяє підвищенню середньодобових приростів під час відлучення.

6. Полішук A. А. Шляхи ефективного вирощування і відгодівлі свиней / А. А. Поліщук // Сільський господар. - 2004. - №1-2. - С. 25-26.

7. Халак В.І. Балансуючі кормові добавки у раціоні свиноматок та поросят / В.І. Халак, А. Н. Майстренко, Г. Г. Дімчя // Агробізнес сьогодні. - №22 (341). - 2016.

8. Чижанська Н. В. Вплив меланіну з антарктичних джерел на збереженість поголів'я поросят при відлученні / Н. В. Чижанська, Т. В. Берегова // Український антарктичний журнал. - №8. 2009. - C. 377-381.

9. Diets that increase mucin production in pigs reduce threonine and amino acid retention [Myrie S. B., Bertolo R. F. P., Sauer W. C. and Ball R. O.] // Advances in Pork Production. - 2003. - V. 14. Abstr 9.

10. Janine Boettger D. Effect of Low Protein Diets on Performance and Energy Metabolism of Sows / Janine Boettger D., Sönke Möhn and Ronald O. Ball // Advances in Pork Production. - 2001. V. 12. - Abstr. 20. 